\title{
A STATISTICAL STUDY OF THE INTERRELATIONS BETWEEN CERTAIN MINERAL CONSTITUENTS OF THE BLOOD OF DAIRY COWS
}

\author{
Pellervo SaARinen
}

Agricultural Research Centre, Department of Animal Husbandry Tikkurila, Finland ${ }^{1}$

Received 20th December 1952

In a previous communication a new factor possibly having a positive effect on the level of calcium in the blood of dairy cows, i.e. increase of the $\mathrm{Ca} / \mathrm{P}$ ratio in the feed, was reported (4). For protecting the cows from hypocalcemia and milk fever more effective methods, e.g. the feeding of calcium and/or ammonium chloride pre and post partum, have been proposed for practical dairying (2). Calcium chloride and, especially, ammonium chloride however, decrease the alkali reserves in the blood. A statistical study of the relationships between the blood mineral composition and the simultaneous milk and milk fat yields (5) indicated a positive correlation with the excess of cations in the blood whereas with the blood chlorides there was a negative correlation with the milk and milk fat yields. Several other minerals in the blood, too, simultaneously appeared to show some positive or negative influence.

According to these results it was evident that the proportions between various minerals can be as effective as the actual amounts and/or the concentrations of these substances. Similar changes in the mineral composition of the blood can be produced in several different ways. Changing the amount of one mineral in the feed can result in changes of two or more minerals in the blood. The effects of these may compensate each other. The few data found in the literature concerning the interrelations between different minerals in the blood of dairy cows were limited to some few minerals only. Moreover, the results were obtained in different environmental conditions. So an additional study of the mutual dependence of the levels of different blood minerals appeared to be necessary before arranging additional feeding trials with different mineral supplements.

1 Present address: Univ. of Helsinki, Department of Animal Husbandry. 


\section{Experimental procedure}

In addition to the analytical data used in the two previous studies $(4,5) 56$ more cows have been used for this study. Only one blood sample was taken from each cow; the total number of samples used in these calculations amounts to 330 , and the no. of single determinations to 3300 .

The range of variation concerning the stage of lactation was $20-252$ days in milk, and the amount of milk varied from 10.9 to $33.6 \mathrm{~kg}$. day. The feed consisted of 15 to $22 \mathrm{lb}$. of roughage (mainly clover - timothy hay and some straw), silage or roots and concentrate mixtures. Calcium phosphate was used as the sole phosphorus supplement and calcium carbonate, together with phosphate, as calcium supplement. The $\mathrm{Ca} / \mathrm{P}$ ratio in the ration was fairly high, varying from 1.07 to 3.91 . The variations in the amounts of sodium and chlorine were mainly due to the sodium chloride given in the feed mixtures or to soda used together with AIV-fodder.

All blood samples were drawn from the coccygeal artery (3). The analytical procedures used were the same as before.

According to the previous study (5) several blood minerals seemed to show some correlation with the milk and milk fat yields. Only the major elements generally used in the mineral supplements, i.e. calcium, phosphorus, sodium and chlorine plus the total excess of cations in the blood, however, have been included in these calculations. The cation excess has been calculated as the difference between the total equivalent amount of $\mathrm{Na}, \mathrm{K}$, and $\mathrm{Ca}$ minus $\mathrm{Cl}$ and the acid-soluble inorganic $\mathrm{P}$. Phosphoric acid has been considered as a bivalent acid only.

For investigating the mutual relationships between the various blood minerals the coefficients of partial correlation have been calculated, assuming that each mineral constituent studied in turn is a variable dependent on the others. The method used in these calculations is the same as was used previously (4).

\section{Results}

The results obtained are presented in tables $1-5$.

The statistical dependence of the blood calcium $\left(\mathrm{x}_{1}\right)$ on four supposedly independent variables, i.e., sodium $\left(\mathrm{x}_{2}\right)$, the cation excess $\left(\mathrm{x}_{3}\right)$, chlorides $\left(\mathrm{x}_{5}\right)$ and inorganic phosphates $\left(\mathrm{x}_{5}\right)$ in the blood is presented in table 1. It will be noticed that the anions, both blood chlorides and phosphates, statistically show a fairly distinct positive influence on the level of the blood calcium. According to the equation presented below, which expresses the effects as a linear function, one milliequivalent of phosphorus in the blood seems to be about nine times as effective as one milliequivalent of chlorine. The excess of inorganic cations in the blood also appears to show a positive influence on the blood calcium. As is seen later from table 3 , this is however only slightly higher than the theoretical correlation between these two variables. According to the coefficient of double correlation, $\mathrm{r}_{12}=0.2087$, a positive correlation between the blood sodium and calcium also appears to exist. If the effects of the 
Table 1. Coefficients of partial correlation when blood calcium $\left(\mathrm{x}_{1}\right)$ is considered as the dependent variable and sodium $\left(\mathrm{x}_{2}\right)$, total cation excess $\left(\mathrm{x}_{3}\right)$, chlorides $\left(\mathrm{x}_{4}\right)$ and inorganic phosphates $\left(\mathrm{x}_{5}\right)$ in milliequivalents per liter of blood as independent variables, $(\mathrm{n}=330)$.

\begin{tabular}{|c|c|c|c|c|c|c|c|}
\hline \multicolumn{2}{|c|}{$\begin{array}{l}\mathrm{x}_{2}=\text { blood } \\
\text { sodium }\end{array}$} & \multicolumn{2}{|c|}{$\begin{array}{c}x_{3}=\text { excess of inorg. } \\
\text { cations in blood }\end{array}$} & \multicolumn{2}{|c|}{$\begin{array}{l}\mathrm{x}_{4}=\text { blood } \\
\text { chlorides }\end{array}$} & \multicolumn{2}{|c|}{$\begin{array}{c}\mathrm{x}_{5}=\text { blood } \\
\text { inorg. phospphates }\end{array}$} \\
\hline $\mathrm{r}_{12}$ & $=+0.2087$ & $\mathrm{r}_{13}$ & $=+0.1988$ & $\mathrm{r}_{14}$ & $=+0.0723$ & $r_{15}$ & $=+0.1214$ \\
\hline $\mathrm{r}_{12,3}$ & $=+0.0902$ & $\mathrm{r}_{13,2}$ & $=\quad+0.0626$ & $\mathrm{r}_{14,2}$ & $=+0.0297$ & $\mathrm{r}_{15,2}^{15}$ & $=+0.1511$ \\
\hline $\mathrm{r}_{12,4}$ & $=+0.1980$ & $\mathrm{r}_{13,4}$ & $=+0.2312$ & $\mathrm{r}_{14,3}$ & $=+0.1402$ & $\mathrm{r}_{153}$ & $=+0.1438$ \\
\hline $\mathrm{r}_{12,5}$ & $=+0.2267$ & $\mathrm{r}_{13,5}$ & $=+0.2128$ & $r_{14,5}$ & $=+0.0891$ & $\mathrm{r}_{15,4}$ & $=+0.1320$ \\
\hline $\mathrm{r}_{12 ; 34}$ & $=-0.0127$ & $\mathrm{r}_{13 ; 24}$ & $=+0.1217$ & $\mathrm{r}_{14 ; 23}$ & $=+0.1086$ & $r_{15 ; 23}$ & $=+0.1518$ \\
\hline $\mathrm{r}_{12 ; 35}$ & $=+0.1025$ & $\mathrm{r}_{13 ; 25}$ & $=+0.0638$ & $\mathrm{r}_{14 ; 25}$ & $=+0.0463$ & $r_{15 ; 24}$ & $=+0.1551$ \\
\hline$r_{12 ; 45}$ & $=+0.2138$ & $\mathrm{r}_{13 ; 45}$ & $=+0.2544$ & $\mathrm{r}_{14 ; 35}$ & $=+0.1677$ & $r_{15 ; 34}$ & $=+0.1707$ \\
\hline $\mathrm{r}_{12 ; 345}$ & $=-0.0227$ & $\mathrm{r}_{13 ; 245}$ & $=+0.1423$ & $\mathrm{r}_{14 ; 235}$ & $=+0.1353$ & $\mathrm{r}_{15 ; 234}$ & $=+0.1717$ \\
\hline
\end{tabular}

Table 2. Coefficients of partial correlation when blood sodium $\left(\mathrm{x}_{2}\right)$ is considered as the dependent variable and calcium $\left(x_{1}\right)$, total cation excess $\left(x_{3}\right)$, chlorides $\left(x_{4}\right)$ and inorganic phosphates $\left(x_{5}\right)$ in milliequivalents per liter of blood as independent variables, $(\mathrm{n}=330)$.

\begin{tabular}{lllll}
\hline $\begin{array}{c}\mathrm{x}_{1}=\text { blood } \\
\text { calcium }\end{array}$ & $\begin{array}{c}\mathrm{x}_{3}=\text { excess of inorg. } \\
\text { cations in blood }\end{array}$ & \multicolumn{1}{c}{$\begin{array}{c}\mathrm{x}_{4}=\text { blood } \\
\text { chlorides }\end{array}$} & $\begin{array}{c}\mathrm{x}_{5}=\text { blood inorg. } \\
\text { phosphates }\end{array}$ \\
\hline $\mathrm{r}_{21}=+0.2087$ & $\mathrm{r}_{23}=+0.7628$ & $\mathrm{r}_{24}$ & $=+0.2104$ & $\mathrm{r}_{25}=-0.1214$ \\
$\mathrm{r}_{21,3}=+0.0902$ & $\mathrm{r}_{23,1}=+0.7526$ & $\mathrm{r}_{24,1}=+0.2002$ & $\mathrm{r}_{251}=-0.1511$ \\
$\mathrm{r}_{21,4}=+0.1980$ & $\mathrm{r}_{23,4}=+0.8837$ & $\mathrm{r}_{24,3}=+0.7067$ & $\mathrm{r}_{25,3}=-0.0761$ \\
$\mathrm{r}_{21,5}=+0.2267$ & $\mathrm{r}_{23,5}=+0.7603$ & $\mathrm{r}_{24,5}=+0.1980$ & $\mathrm{r}_{25,4}=-0.0977$ \\
$\mathrm{r}_{21 ; 34}=-0.0127$ & $\mathrm{r}_{23 ; 14}=+0.8787$ & $\mathrm{r}_{24 ; 13}=+0.7039$ & $\mathrm{r}_{25 ; 13}=-0.0904$ \\
$\mathrm{r}_{21 ; 35}=+0.1025$ & $\mathrm{r}_{23 ; 15}=+0.7482$ & $\mathrm{r}_{24 ; 15}=+0.1833$ & $\mathrm{r}_{25 ; 14}=-0.1274$ \\
$\mathrm{r}_{21 ; 45}=+0.2138$ & $\mathrm{r}_{23 ; 45}=+0.8829$ & $\mathrm{r}_{24 ; 35}=+0.7057$ & $\mathrm{r}_{25 ; 34}=+0.0562$ \\
$\mathrm{r}_{21 ; 345}=-0.0227$ & $\mathrm{r}_{23 ; 145}=+0.8770$ & $\mathrm{r}_{24 ; 135}=+0.7022$ & $\mathrm{r}_{25 ; 134}=+0.0592$ \\
\hline
\end{tabular}

$x_{2}=10.04-1.758 \cdot x_{1}+0.8717 \cdot x_{3}+0.8051 \cdot x_{4}+0.4684 \cdot x_{5}$

Table 3. Coefficient of partial correlation when the total excess of cations in blood $\left(\mathrm{x}_{3}\right)$ is considered as the dependent variable and blood calcium $\left(\mathrm{x}_{1}\right)$, sodium $\left(\mathrm{x}_{2}\right)$ chlorides $\left(\mathrm{x}_{4}\right)$ and phosphates $\left(\mathrm{x}_{5}\right)$ in milliequivalents per liter of blood as independent variables, $(\mathrm{n}=330)$.

\begin{tabular}{|c|c|c|c|c|c|c|c|c|c|c|c|}
\hline \multicolumn{3}{|c|}{$\begin{array}{c}\mathrm{x}_{1}=\text { blood } \\
\text { calcium }\end{array}$} & \multicolumn{3}{|c|}{$\begin{array}{l}\mathrm{x}_{2}=\text { blood } \\
\text { sodium }\end{array}$} & \multicolumn{3}{|c|}{$\begin{array}{l}\mathrm{x}_{4}=\text { blood } \\
\text { chlorides }\end{array}$} & \multicolumn{3}{|c|}{$\begin{array}{l}\qquad x_{5}=\text { blood } \\
\text { inorg. phosphates }\end{array}$} \\
\hline$x_{31}$ & $=$ & +0.1988 & $\mathrm{x}_{32}$ & $=$ & +0.7628 & $\mathrm{r}_{34}$ & $=$ & -0.2963 & $x_{35}$ & $=$ & -0.0949 \\
\hline$x_{31,2}$ & & +0.0626 & $x_{32,1}$ & $=$ & +0.7526 & $\mathrm{r}_{34,1}$ & $=$ & -0.3179 & $\mathrm{x}_{35,1}$ & $=$ & -0.1223 \\
\hline$x_{31,4}$ & $=$ & +0.2312 & $\mathrm{x}_{32,4}$ & $=$ & +0.8837 & $\mathrm{r}_{34,2}$ & $=$ & -0.7226 & $x_{35,2}$ & $=$ & -0.0036 \\
\hline$x_{315}$ & $=$ & +0.2128 & $\mathrm{x}_{32,5}$ & $=$ & +0.7603 & $\mathrm{r}_{34,5}$ & $=$ & -0.3123 & $x_{35,4}$ & $=$ & -0.1399 \\
\hline $\mathrm{x}_{31 ; 24}$ & $=$ & +0.1217 & $\mathrm{x}_{32 ; 14}$ & $=$ & +0.8787 & $\mathrm{r}_{34 ; 12}$ & $=$ & -0.7264 & $\mathrm{x}_{35 ; 12}$ & $=$ & -0.0132 \\
\hline$x_{31 ; 25}$ & $=$ & +0.0638 & $x_{32 ; 15}$ & $=$ & +0.7482 & $\mathrm{r}_{34 ; 15}$ & $=$ & -0.3405 & $\mathrm{x}_{35 ; 14}$ & $=$ & -0.1766 \\
\hline $\mathrm{x}_{31 ; 45}$ & $=$ & +0.2544 & $\mathrm{x}_{32 ; 45}$ & $=$ & +0.8829 & $\mathrm{r}_{34 ; 25}$ & $=$ & -0.7269 & $\mathrm{x}_{35,24}$ & $=$ & -0.1152 \\
\hline$x_{31 ; 245}$ & $=$ & +0.1423 & $\mathrm{x}_{32 ; 145}$ & $=$ & +0.8770 & $\mathrm{r}_{34 ; 125}$ & $=$ & -0.7324 & $\mathrm{x}_{35 ; 124}$ & $=$ & -0.1367 \\
\hline
\end{tabular}

$\mathrm{x}_{3}=11.92+1.1086 \cdot \mathrm{x}_{1}+0.8823 \cdot \mathrm{x}_{2}-0.8447 \cdot \mathrm{x}_{4}-1.0876 \cdot \mathrm{x}_{{ }_{5}}$ 
Table 4. Coefficients of partial correlation when blood chlorides $\left(\mathrm{x}_{4}\right)$ are considered as the dependent variable and calcium $\left(\mathrm{x}_{1}\right)$, sodium $\left.\mathrm{x}_{2}\right)$, total cation excess $\left(\mathrm{x}_{3}\right)$ and inorganic phosphates $\left(\mathrm{x}_{5}\right)$ in milliequivalents per liter of blood as independent variables, $(\mathrm{n}=330)$.

\begin{tabular}{lllll}
\hline \multicolumn{1}{c}{$\begin{array}{c}\mathrm{x}_{1}=\text { blood } \\
\text { calcium }\end{array}$} & \multicolumn{1}{c}{$\begin{array}{c}\mathrm{x}_{2}=\text { blood } \\
\text { sodium }\end{array}$} & $\begin{array}{c}\mathrm{x}_{3}=\text { excess of inorg. } \\
\text { cations in blood }\end{array}$ & \multicolumn{1}{c}{$\begin{array}{c}\mathrm{x}_{5}=\text { blood inorg. } \\
\text { phosphates. }\end{array}$} \\
\hline $\mathrm{r}_{41}=+0.0723$ & $\mathrm{r}_{42}=+0.2104$ & $\mathrm{r}_{43}=-0.2963$ & $\mathrm{r}_{45}=-0.1270$ \\
$\mathrm{r}_{41,2}=+0.0297$ & $\mathrm{r}_{42,1}=+0.2002$ & $\mathrm{r}_{43,1}=-0.3179$ & $\mathrm{r}_{45,1}=-0.1372$ \\
$\mathrm{r}_{413}=+0.1402$ & $\mathrm{r}_{42,3}=+0.7067$ & $\mathrm{r}_{43,2}=-0.7226$ & $\mathrm{r}_{45,2}=-0.1046$ \\
$\mathrm{r}_{41,5}=+0.0891$ & $\mathrm{r}_{42,5}=+0.1980$ & $\mathrm{r}_{43,5}=-0.3123$ & $\mathrm{r}_{45,3}=-0.1631$ \\
$\mathrm{r}_{41 ; 23}=+0.1086$ & $\mathrm{r}_{42 ; 13}=+0.7039$ & $\mathrm{r}_{43 ; 12}=-0.7264$ & $\mathrm{r}_{45 ; 12}=-0.1104$ \\
$\mathrm{r}_{41 ; 25}=+0.0463$ & $\mathrm{r}_{42 ; 15}=+0.1833$ & $\mathrm{r}_{43 ; 15}=-0.3405$ & $\mathrm{r}_{45 ; 13}=-0.1871$ \\
$\mathrm{r}_{41 ; 34}=+0.1677$ & $\mathrm{r}_{42 ; 35}=+0.7057$ & $\mathrm{r}_{43,25}=-0.7269$ & $\mathrm{r}_{45 ; 23}=-0.1549$ \\
$\mathrm{r}_{41 ; 235}=+0.1353$ & $\mathrm{r}_{42 ; 135}=+0.7022$ & $\mathrm{r}_{43 ; 125}=-0.7324$ & $\mathrm{r}_{45 ; 123}=-0.1746$ \\
\hline
\end{tabular}

$\mathrm{x}_{4}=38.60+0.9150 \cdot \mathrm{x}_{1}+0.6124 \cdot \mathrm{x}_{2}-0.6350 \cdot \mathrm{x}_{3}-1.2058 \cdot \mathrm{x}_{5}$

Table 5. Coefficients of partial correlation when blood inorg. phosphates $\left(\mathrm{x}_{5}\right)$ are considered as the dependent variable and calcium $\left(\mathrm{x}_{1}\right)$, sodium $\left(\mathrm{x}_{2}\right)$, total cation excess $\left(\mathrm{x}_{3}\right)$ and chlorides $\left(\mathrm{x}_{4}\right)$ in milliequivalents per liter of blood as independent variables, $(\mathrm{n}=33 \mathrm{e})$.

\begin{tabular}{llllll}
\hline \multicolumn{1}{c}{$\begin{array}{c}\mathrm{x}_{1}=\text { blood } \\
\text { calcium }\end{array}$} & \multicolumn{1}{c}{$\begin{array}{c}\mathrm{x}_{2}=\text { blood } \\
\text { sodium }\end{array}$} & $\begin{array}{c}\mathrm{x}_{3}=\text { excess of inor } \\
\text { cations in blood }\end{array}$ & $\begin{array}{c}\mathrm{x}_{4}=\text { blood } \\
\text { chlorides }\end{array}$ \\
\hline $\mathrm{r}_{51}=+0.1214$ & $\mathrm{r}_{52}=-0.1214$ & $\mathrm{r}_{53}=-0.0949$ & $\mathrm{r}_{54}$ & $=-0.1270$ \\
$\mathrm{r}_{51,2}=+0.1511$ & $\mathrm{r}_{52,1}=-0.1511$ & $\mathrm{r}_{53,1}=-0.1223$ & $\mathrm{r}_{54,1}=-0.1372$ \\
$\mathrm{r}_{51,3}=+0.1438$ & $\mathrm{r}_{52,3}=-0.0761$ & $\mathrm{r}_{53,2}=-0.0036$ & $\mathrm{r}_{54,2}=-0.1046$ \\
$\mathrm{r}_{51,4}=+0.1320$ & $\mathrm{r}_{52,4}=-0.0977$ & $\mathrm{r}_{53,4}=-0.1399$ & $\mathrm{r}_{54,3}=-0.1631$ \\
$\mathrm{r}_{51 ; 23}=+0.1518$ & $\mathrm{r}_{52 ; 13}=-0.0904$ & $\mathrm{r}_{53 ; 12}=-0.0132$ & $\mathrm{r}_{54 ; 12}=-0.1104$ \\
$\mathrm{r}_{51 ; 24}=+0.1551$ & $\mathrm{r}_{52 ; 14}=-0.1274$ & $\mathrm{r}_{53 ; 14}=-0.1766$ & $\mathrm{r}_{54 ; 13}=-0.1871$ \\
$\mathrm{r}_{51 ; 34}=+0.1707$ & $\mathrm{r}_{52 ; 34}=+0.0562$ & $\mathrm{r}_{53 ; 24}=-0.1152$ & $\mathrm{r}_{54 ; 23}=-0.1549$ \\
$\mathrm{r}_{51 ; 234}=+0.1717$ & $\mathrm{r}_{52 ; 134}=+0.0592$ & $\mathrm{r}_{53 ; 124}=-0.1367$ & $\mathrm{r}_{54 ; 123}=-0.1746$ \\
\hline \multicolumn{7}{c}{$\mathrm{x}_{5}=4.13+0.1681 \cdot \mathrm{x}_{1}+0.0075 \cdot \mathrm{x}_{2}-0.0172 \cdot \mathrm{x}_{3}-0.0253 \cdot \mathrm{x}_{4}$} \\
\hline
\end{tabular}

excess of cations in the blood and that of chlorides, however, are taken into consideration, the effect of the blood sodium is statistically insignificant or slightly negative. This suggests that these variables, rather than the blood sodium, have affected the blood calcium.

The statistical dependence of the blood sodium $\left(\mathrm{x}_{2}\right)$ on the other four, supposedly independent, variables is presented in table 2 . It will be noticed that the blood chlorine is closely correlated with the blood sodium, $r_{24: 13 i}=+0.7022$. Also the excess of cations in the blood statistically shows a high correlation with blood sodium which, however, is possibly not higher than the theoretical one.

The statistical dependence of the total excess of cations in the blood $\left(\mathrm{x}_{3}\right)$ on the blood calcium $\left(\mathrm{x}_{1}\right)$, sodium $\left(\mathrm{x}_{2}\right)$, chlorides $\left(\mathrm{x}_{4}\right)$ and inorganic phosphates $\left(\mathrm{x}_{5}\right)$ is presented in table 3 . Theoretically the cations should increase and the anions de- 
crease the excess of cations to an equivalent extent. Owing to the larger variations in the amounts of blood sodium and chlorine, variations in the excess of cations in the blood are in practice mainly dependent on these minerals. This will be noticed also from the results presented in table 3. No distinct special effects on the excess of cations can be observed in this table. According to the equation presented below the table the blood calcium has exhibited a slightly more positive effect than the blood sodium and the blood inorganic phosphorus a slightly more negative effect than the chlorine. This result, however, may be purely fortuitous.

The statistical dependence of blood chlorides $\left(\mathrm{x}_{4}\right)$ on blood calcium $\left(\mathrm{x}_{1}\right)$, sodium $\left(x_{2}\right)$, the cation excess $\left(x_{3}\right)$ and inorganic phosphates in the blood $\left(x_{5}\right)$ is presented in table 4 . The close positive correlation between blood sodium and chlorine, and the somewhat less distinct positive correlation between blood calcium and chlorine, as well as the negative correlation of the excess of cations to blood chlorine, will also be noticed in this table. In addition to this it will be observed that the inorganic phosphates in the blood statistically show a reciprocal correlation with the blood chlorine. According to the equation presented below the table inorganic phosphorus has replaced more than the equivalent amount of chlorine in the blood, if phosphoric acid is considered as a bivalent acid.

The coefficients of correlation showing the statistical dependence of blood inorganic phosphorus $\left(\mathrm{x}_{5}\right)$ on the four supposedly independent variables $\mathrm{x}_{1}-\mathrm{x}_{4}$ are presented in table 5. The positive statistical correlation of blood calcium and sodium, as well as the negative statistical correlation of blood chlorides, and the excess of cations in the blood to the inorganic phosphates will also be observed in this table.

\section{Discussion}

The results obtained are obviously affected by the type of feeding and only partially represent a physiological stability. When evaluating these results both groups of factors must be taken into consideration.

Regarding the positive effects asserted to be obtainable with chlorides in maintaining the blood calcium at high level, this study has given a fairly positive result. When using sodium chloride as supplement instead of calcium or ammonium chloride and when the blood alkali reserves have been maintained simultaneously, the phosphates, however, appear to be proportionately more effective than the chlorides.

When calcium phosphate has been used as a supplement no reciprocal relationship of blood calcium and inorganic phosphorus has been noticed, as reported earlier of sheep on different feeding regimes (1).

The maintaining of the total excess of cations in the blood at a fairly high level, i.e., about 50 milliequivalents per liter of blood on average, has not shown any detrimental effect on the blood calcium. Thus the decreasing of the blood alkali reserve as a means of increasing the blood calcium appears not to be desirable.

Also the positive effects of chlorides and phosphates appear to be relatively slight, and some other methods, e.g. using calcium in excess and/or a high $\mathrm{Ca} / \mathrm{P}$ 
ratio in the ration may possibly be preferable in feeding dairy cows (4). That an increase in the blood calcium is in fact, possible even when the amount of chlorides in the ration is simultaneously decreased when calcium is added has been reported previously (5).

The reciprocal statistical correlation apparently existing between blood phosphates and chlorides appears to indicate that an excessive feeding of chlorides removes phosphorus from the blood, or vice versa. A disproportion between these two might increase the requirements of these elements.

The close statistical correlation between sodium and chlorine in the blood appears to indicate a certain stability in the composition of the blood. The possibility of removing one of these elements from the blood by excessive feeding of the other appears to be very limited.

\section{Summary and conclusions}

A statistical study of interrelations between some blood minerals was made on the basis of 330 arterial blood samples collected from 16 herds. The mutual dependence of five variables, calcium $\left(\mathrm{x}_{1}\right)$, sodium $\left(\mathrm{x}_{2}\right)$, the total excess of cations $\left(\mathrm{x}_{3}\right)$, chlorine $\left(\mathrm{x}_{4}\right)$, and inorganic phosphorus in the blood $\left(\mathrm{x}_{5}\right)$, was investigated simultaneously. For this purpose the coefficients of partial correlation were calculated and the dependence of each mineral studied was expressed as a linear function of the others.

If the effects of all the minerals studied were taken into consideration simultaneously the inorganic anions in the blood showed a slight positive correlation with the blood calcium or vice versa, $r_{14 ; 235}=+0.1353$ and $r_{15 ; 234}=+0.1717$. The phosphates appeared to be proportionately more effective than the chlorides. No reciprocal relationship was noticed between calcium and inorganic phosphorus in the blood of dairy cows

Blood chlorine and inorganic phosphorus in the blood were reciprocally related, $\mathrm{r}_{45 ; 123}=-0.1746$; hence it is concluded that an excessive feeding of chlorides can remove phosphorus from the blood and affect the requirements.

Blood sodium and chlorine were fairly closely correlated, $\mathrm{r}_{24 ; 135}=+0.7022$, and the possibilities of removing one of these elements from the blood by feeding the other in excess appear to be limited.

Regarding the positive effects asserted to be obtainable with chlorides in maintaining the blood calcium at high level the study has given a fairly positive result. If, however, the excess of cations in he blood is maintained simultaneously at a normal level the effect of chlorides on the blood calcium appears to be very slight and in practice some other methods may be preferable. 


\section{Acknowledgements}

The author wishes to extend his sincere thanks to I. PoIJÄrvi, Head of the Department of Animal Husbandry, for making the necessary arrangements to conduct this study and to Mrs. Katri SaARinen for her assistance in calculating the analytical and statistical data. This work was supported in part by a grant from the Suomen Kulttuurirahasto.

\section{REFERENCES}

(1) Fraser, Allan Henry Hector. 1932. The reciprocal relationship of calcium and inorganic phosphorus of the blood of sheep. Bioch. J., p. 2166-2168.

(2) Hilden, E. 1951. Poikimahalvaus uusimpien tutkimusten valossa. Suomen Karja, 5, p. 5-6.

(3) SAARinen, P. 1938. Einfaches Verfahren zur Gewinnung von Arterienblutproben beim Rindvieh. J. Sci. Agr. Soc. Finland, 10, p. 140-146.

(4) - - 1950. A statistical study of the effect of excessive feeding of calcium and phosphorus supplements on the blood calcium and phosphorus of dairy cows. Ibid., 22, p. 122-131.

(5) _ - 1952. A preliminary study of the relationships between the blood mineral composition of dairy cows and the milk and milk fat yield simultaneously obtained. Ibid. ,24, p. 170-175.

\section{SELOST US:}

\section{TILASTOLLINEN TUTKIMUS LEHMÄN VEREN ERÄIDEN KIVENNÄISAINEOSIEN VÄLISISTÄ KESKIN ̈̈ISISTÄ VUOROSUHTEISTA}

$$
\text { P. SAARINEN }
$$

Maatalouskoelaitos, kotieläinhoito-osasto, Tikkurila

Edellä selostettu tutkimus, joka perustuu 16 karjasta kerätyn 330 valtimoverinäytteen kivennäismäärityksiin (yhteensä 3300 määritystä), on suoritettu tilastollista menetelmää käyttäen. Veren kalsiumin $\left(\mathrm{x}_{1}\right)$, natriumin $\left(\mathrm{x}_{2}\right)$, emäsylimäärän $\left(\mathrm{x}_{3}\right)$, kloorin $\left(\mathrm{x}_{4}\right)$ ja epäorganisen fosforin $\left(\mathrm{x}_{5}\right)$ määrien riippuvaisuutta toisistaan on tutkittu laskemalla kullekin näistä osittaiskorrelatiokertoimet olettaen muut riippumattomiksi muuttujiksi ja tutkittava suure näiden linearifunktioksi.

Kun kaikkien edellämainittujen kivennäisaineiden vaikutukset otettiin samanaikaisesti huomioon, niin veren epäorganisten anionien ja veren kalsiumipitoisuuden välillä tutkittavassa aineistossa esiintyi lievä positiivinen vuorosuhde, $\mathrm{r}_{14 ; 235}=+0.1353$ ja $\mathrm{r}_{15 ; 234}=+0.1717$, mikä viittaisi siihen, että klorideilla ja fosfaateilla olisi veren kalsiumpitoisuutta nostava vaikutus tai päinvastoin. Fosfaattien vaikutus näytti olevan suhteellisesti voimakkaampi kuin kloridien vaikutus. Veren kalsiumin ja fosforin välillä aikaisemmin todettua negatiivista vuorosuhdetta tässä materiaalissa ei esiintynyt.

Veren kloridien ja epäorganisten fosfaattien välillä esiintyi lievä negatiivinen vuorosuhde, $\mathrm{r}_{45 ; 123}=$ — 0.1746, josta päätellen kloridit ylimäärin käytettyinä voivat huuhtoa verestä fosfaatteja ja näennäisesti lisätä eläimen fosforin tarvetta tai päinvastoin.

Veren natriumin ja kloorin välillä voitiin todeta verrattain kiinteä vuorosuhde, $r_{24 ; 135}=+0.7022$. Mahdollisuus huuhtoa jompaakumpaa näistä kivennäisaineista pois verestä syöttämällä toista ylimäärin näyttää olevan verraten rajoitettu.

Veren kalsiumpitoisuuden pysyttäminen korkeana syöttämällä lehmälle klorideja näyttää olevan teoriassa mahdollista. Jos kuitenkin samanaikaisesti halutaan ylläpitää veressä normaalinen emäsylimäärä, niin silloin tämän toimenpiteen merkitys näyttää suhteellisen vähäiseltä. Käytännössä muunlaiset menettelytavat voivatkin osoittautua suositeltavammiksi. 